\title{
SIMULATION OF GPR SYSTEM DESIGN USING CST MICROWAVE AND MATLAB
}

\author{
Ariffuddin Joret $^{1}$, M. F. L. Abdullah ${ }^{1}$, and Muhammad Suhaimi Sulong ${ }^{1}$ \\ ${ }^{1}$ Faculty of Electrical and Electronic Engineering, \\ Universiti Tun Hussein Onn Malaysia, Johor, Malaysia \\ E-mail: ariff@uthm.edu.my
}

\begin{abstract}
Ground Penetrating Radar (GPR) is a radar system used to detect objects buried underground. The GPR system consists of an antenna which will be used as a sensor device in detecting microwave signal generated by it, which called monostatic or two antennas used as transmitter and receiver antenna known as bistatic GPR system. In the development of a GPR system, it is wise to simulate the GPR system using simulation software such as CST microwave software in order to reduce errors in determining the parameters of the system such as antenna's dimension and signal processing system. The design of the simulation system of the GPR system in this study started from designing an antenna, where the microstrip patch antenna has been chosen. The simulation of the design antenna was then upgraded by the designing of the ground material in front of the antenna to create a medium of transmission such as sandy soil. In order to observe the capability of the designed antenna as the GPR antenna system as well as the signal processing system, the buried material in the ground has been added. As the consideration of the GPR system is on the bistatic GPR system, the antenna will be paired between the transmitting and receiving antenna. Based on the commercial GPR system, the simulation of the GPR system will also be interpreted as a 2 dimensional image using MATLAB software.
\end{abstract}

Keywords: Microstrip Antenna, Ground Penetrating Radar, CST, MATLAB.

\section{INTRODUCTION}

Ground Penetrating Radar (GPR) is one of techniques can be used to determine material buried underground. The GPR is classified as non-destructive testing (NDT) technique in evaluating underground as the technique did not involve the excavation process. Several applications involving the use of GPR systems include the capability to detect surface crack in the tunnel lining [1], rebar detection [2] and concrete structures condition monitoring [3]. GPR system has been studied for planetary exploration in estimating the subsurface targets. In [4], Lauro found that the location of dielectric targets, whose depths and dimensions are comparable to antenna separation and to the operating wavelengths to be quite accurate using GPR instruments. In connection with the previous studies, in [5] Valerio has studied the ability of GPR to detect rocks buried in composite soil numerically. It is to define feasible sites for shallow drilling of the Martian subsurface before the launch of ExoMarss Mission. Several researchers have used simulation 
software in the study of the GPR system. In [6], Valerio has implemented a full-wave electromagnetic simulator to model the operating environment which is the Martian subsurface. His aims to investigate the capability of a typical GPR system which placed in a ground interface to derive $3 \mathrm{D}$ information on the features of buried dielectric targets. In [7] Galli has also used the CAD tool, as well as others whose have used the simulation software in studying GPR including $[6,7,8,9]$. Based on the use of simulation software in GPR studies, the software can be used as a tool to estimate the parameters of a GPR system which mainly involve in the designing of the antenna. In this research, the GPR system was simulated starting from the designing antenna to the complete GPR system. The antenna chosen for the simulation system of GPR was the microstrip patch rectangular antenna. The consideration of the GPR system in this simulation was the bistatic GPR system which uses two antennas as transmitter and receiver. The operating frequency of the simulation GPR system has been set to $1.8 \mathrm{GHz}$. In this simulation, the sinusoidal of $1.8 \mathrm{GHZ}$ signal has been modulated by an input impulse signal with frequency band of 0 to $1 \mathrm{GHz}$. The simulation result of the GPR system from the CST software was then be imported to the MATLAB software for the GPR profile image construction. Microstrip Patch Antenna, referring to $[9,10]$, the benefits of microstrip patch antenna are easily fabricated and can be printed directly onto a circuit board. The square or rectangular microstip patch antenna can be designed using this formula $[11,12]$ :

$\mathrm{W}=\frac{c}{2 f_{o}} \sqrt{\frac{2}{\varepsilon_{r}+1}} ; \quad \varepsilon_{\mathrm{eff}}=\frac{\varepsilon_{\mathrm{r}}+1}{2}+\frac{\varepsilon_{\mathrm{r}}-1}{2}\left[1+12 \frac{h}{w}\right]$

$$
L=\frac{c}{2 f_{0} \sqrt{\varepsilon_{\text {eff }}}}-0.824 h\left(\frac{\left(\varepsilon_{\text {eff }}+0.3\right)\left(\frac{W}{h}+0.264\right)}{\left(\varepsilon_{\text {eff }}-0.258\right)\left(\frac{W}{h}+0.8\right)}\right)
$$

where $c$ is the velocity of light which is $3 \times 10^{8} \mathrm{~m} / \mathrm{s}, W$ is the width of the patch, $L$ is the length of the patch while $\varepsilon_{\mathrm{r}}$ is the permittivity of the substrate with $h$ is the thickness of the substrate, $f_{0}$ is the center frequency and $\varepsilon_{\text {eff }}$ is the effective dielectric constant.

\section{METHODOLOGY}

In this study, the microstrip rectangular antenna was designed to be operated at 1.8 $\mathrm{GHz}$ operating frequency. After obtaining the required S11 parameter of the antenna, the output signal of the simulation will be focused. This output signal which was the calculated value of the default input signal using Finite Integration Technique (FIT) by the CST software $[13,14,15,16]$ was then exported into MATLAB software for analyzing and processing. The proposed algorithm applied to this output signals was the amplitude demodulation algorithm.

\subsection{GPR ANTENNA DESIGN}

The design of the GPR antenna in this work has been done by using CST microwave simulation software. The shape of the microstrip patch antenna used was the rectangular with width, $W$ of $51 \mathrm{~mm}$ and length, $L$ of $38 \mathrm{~mm}$. The operating frequency, $f_{0}$ of the antenna is about $1.8 \mathrm{GHz}$. The antenna has been designed on FR-4 substrate with thickness, $h$ of $4.5 \mathrm{~mm}$. The specifications of the substrate for dielectric permittivity, Er are 4.7. Figure 1 shows the design of the GPR antenna. 


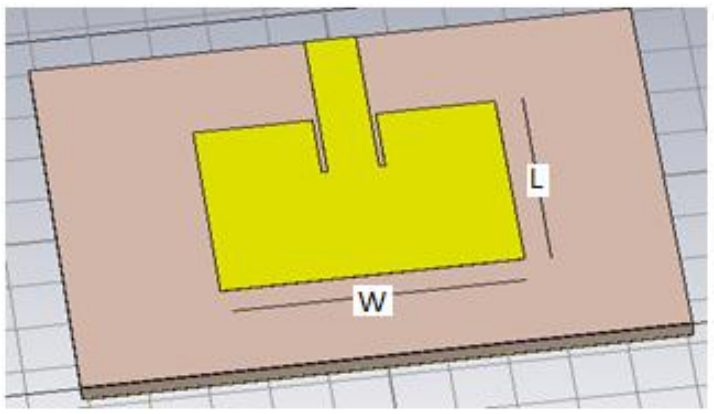

Fig. 1. Rectangular microstrip antenna.

\subsection{SIMULATION OF GPR SYSTEM}

The bistatic GPR system uses two antennas for transmitting and receiving of the electromagnetic wave signal. Based on this type of GPR system, the consideration on the antenna setup is shown in Figure 2. The spacing between the two antennas is about $10 \mathrm{~mm}$ which is about $0.6 \lambda_{0}$ where $\lambda_{0}$ is the wavelength for carrier frequency $(1.8 \mathrm{GHz})$.

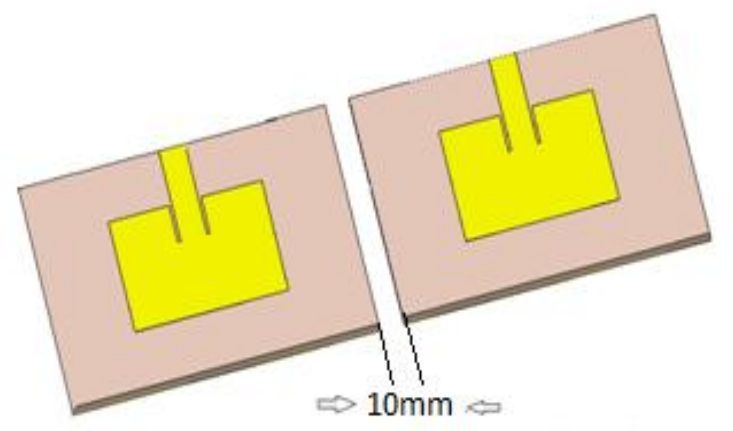

Fig. 2. Bistatic GPR antenna system orientation.

The complete simulation system of the GPR system is shown in Figure 3. The simulated ground material in this study was sandy soil with $\varepsilon_{\mathrm{r}}=2.53$. Figure- 4 shows the simulation of GPR system with embedded iron of size $200 \mathrm{~mm} \times 600 \mathrm{~mm} \times 100 \mathrm{~mm}$ for width, length and thick respectively. The conductivity of iron is $1.04 \times 10^{7} \mathrm{~S} / \mathrm{m}$. Based on Figure 4, the scanning procedure of this GPR system was set by following the arrow's direction. The dimension of the ground was $600 \mathrm{~mm}$ width, $600 \mathrm{~mm}$ length and $500 \mathrm{~mm}$ depth.

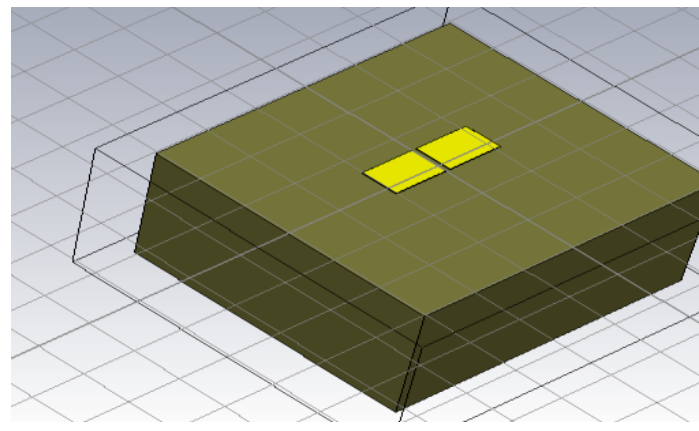

Fig. 3. GPR simulation design.

The scanning step has been set to $10 \mathrm{~mm}$ with the total number of scanning points to be 53. Five conditions of buried iron in the simulation have been analyzed which are:

a. Simulation of GPR system with no embedded iron,

b. Simulation of GPR system with embedded iron at a depth of $56 \mathrm{~mm}$ which is about $0.3 \lambda$,

c. Simulation of GPR system with embedded iron at depth of $106 \mathrm{~mm}$ $(0.5 \lambda), 4)$ simulation of GPR system with embedded iron at depth of $206 \mathrm{~mm}(\lambda)$ and 5) simulation of GPR system with embedded iron at depth

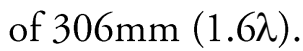

The selection has been chosen as based on the wavelength of the Gaussian signal used in the GPR system refers to formula [17]:

$$
\lambda=\frac{c}{B \sqrt{\varepsilon_{r}}}
$$

where $\lambda$ is the length of wavelength in meters, $c$ is the speed of electromagnetic waves in air, measured as $3 \times 10^{8} \mathrm{~m} / \mathrm{s}, B$ is the frequency band the GPR system equipment, measured in hertz and $\varepsilon_{r}$ is medium permittivity of sandy soil which is about 2.53. Referring to this formula (3), wavelength of the GPR system is about $189 \mathrm{~mm}$. In the CST software, the frequency of the simulation has been set to $1.3 \mathrm{GHz}$ to $2.3 \mathrm{GHz}$. This selection produces an input impulse signal 0 to $1 \mathrm{GHz}$ 
bandwidth of modulated pulse with carrier frequency of $1.8 \mathrm{GHz}$.

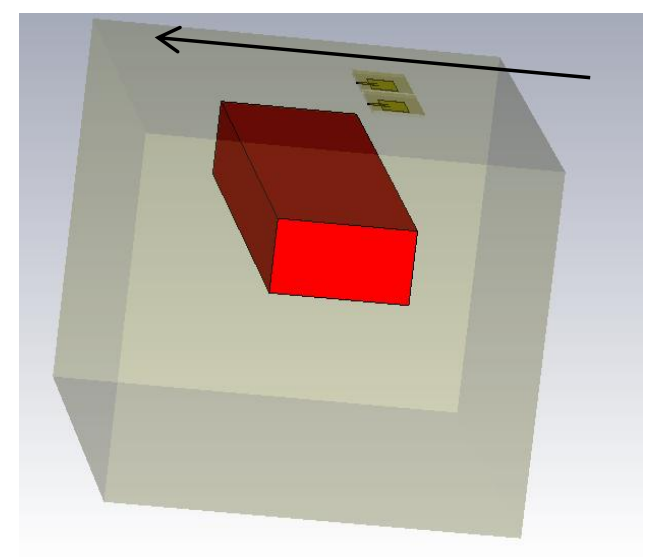

Fig. 4. GPR simulation design with embedded iron.
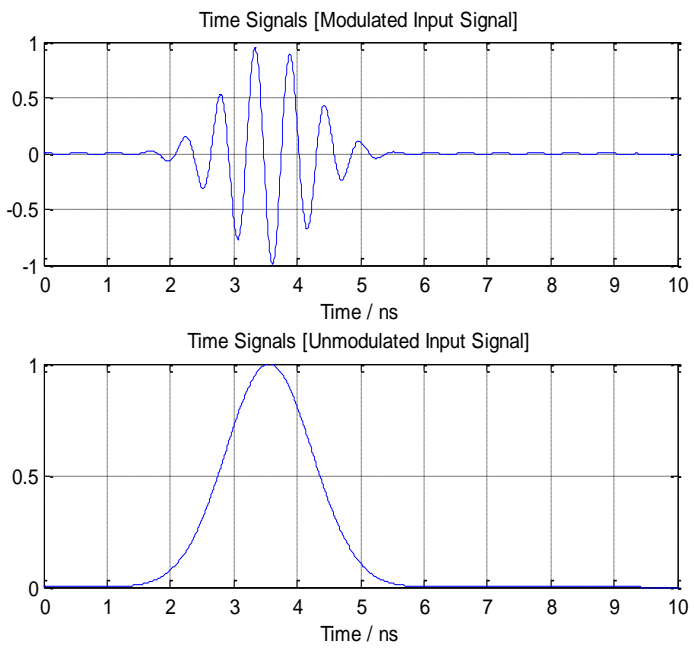

Fig. 5. Example of Input Signal

The example of this input impulse signal is shown in Figure 5. In order to construct the GPR profile image, the output signal calculated from the CST software need to be demodulated. The demodulated of this output signal has been done in MATLAB software. Figure 6 shows the example of modulated and unmodulated output signal of the GPR system simulation at simulated point 23.

\subsection{Signal Processing of the GPR system SIMULATION}

In this simulation, the signal processing algorithm applied on the output signal calculated by the CST software is the amplitude demodulation command of the MATLAB software. The lowpass filter of the algorithm used is the butterworth filter of order 5 with cutoff frequency at $3.6 \mathrm{GHz}$.
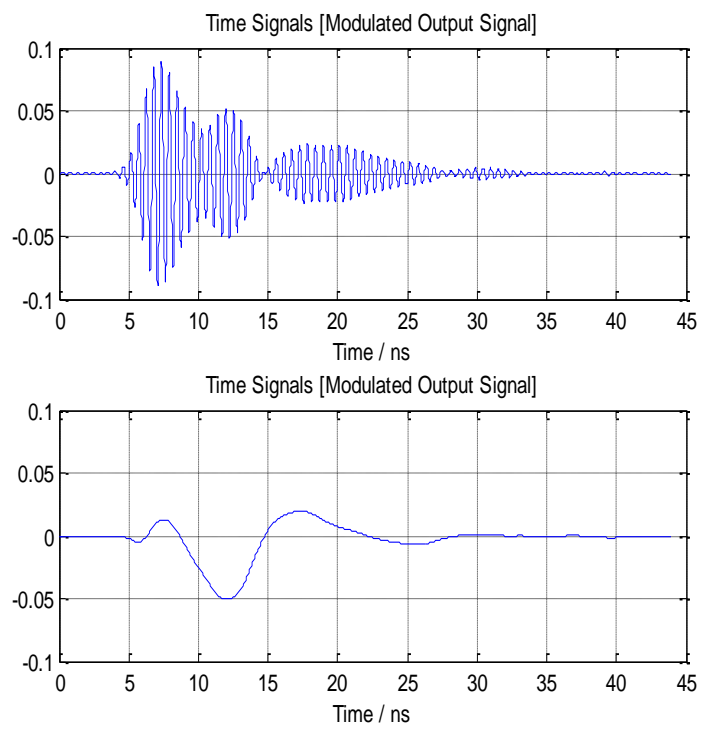

Fig. 6. Example of Output Signa

\subsection{GPR PROFILE IMAGE}

The simulation results of the GPR system which is 53 output signals considered as a signal of scanning points was exported to the MATLAB software to construct the GPR profile image. The output signal which was the modulated pulse signal has to be demodulated first for each scanning point. After the demodulation procedure, these output signals which is the pulse signal has been rearranged in a matrix form. This matrix data then has been transformed into an image of GPR profile.

\section{RESULTS AND DISCUSSION}

The results that was analyzed in this study including the S11 parameter of the rectangular antenna, the S21 and S11 parameter of the rectangular antenna put side by side and the GPR profile images produce by the simulation of GPR system. 


\subsection{ANTENNA DESIGN}

The S11 parameter of the rectangular microstrip patch antenna was as shown in Figure 7. The operating frequency of the designed antenna is about $1.8 \mathrm{GHz}$ as shown by the shallow notch under $-10 \mathrm{~dB}$. Considering the radiation pattern of the rectangular microstrip patch antenna is unidirectional, it is suitable to be used as GPR antenna. This antenna characteristic has been shown in Figure 8 for the designed GPR antenna which is proven to be unidirectional. It shows that the main lobe magnitude is about $6.78 \mathrm{dBi}$ with the direction of $\mathrm{z}$ axis of the simulation antenna design. Considering the radiation pattern of the rectangular microstrip patch antenna is unidirectional, it is suitable to be used as GPR antenna. This antenna characteristic has been shown in Figure 8 for the designed GPR antenna which is proven to be unidirectional.

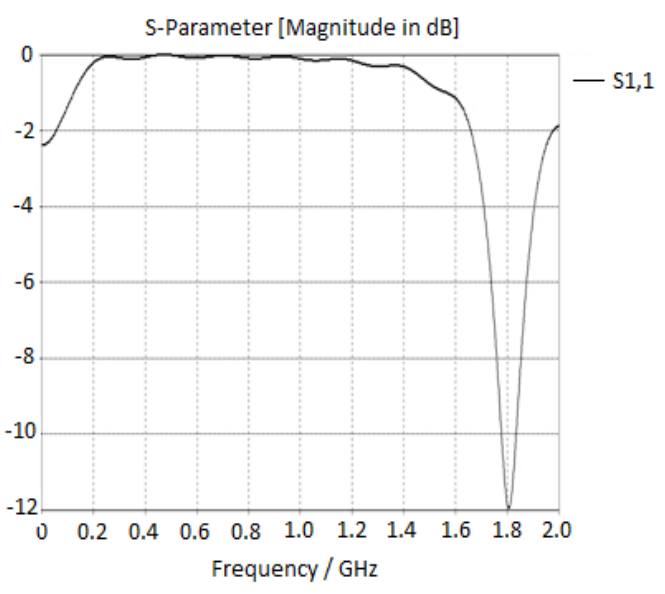

Fig. 7. $\$ 11$ parameter of designed GPR antenna.

It shows that the main lobe magnitude is about $6.78 \mathrm{dBi}$ with the direction of $\mathrm{z}$ axis of the simulation antenna design. Refering to [18], the high gain achievement of this antenna design is due to the big size of the width $(w)$ of the microstrip antenna which was said can control the radiation pattern of the antenna. Another reason of the higher gain achievement by this antenna is the thickness ( $b$ ) of the substrate which is much smaller than the wavelength of operation that affects the efficiency of the antenna.

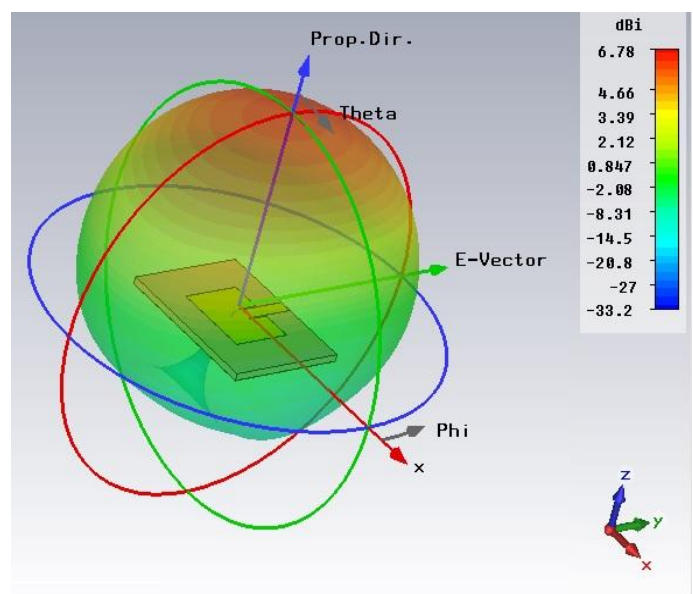

Fig. 8. Radiation pattern of designed GPR antenna.

\subsection{PAIRING OF GPR ANTENNA}

In bistatic GPR system, the most important parameter to be considered is the $\mathrm{S} 21$.

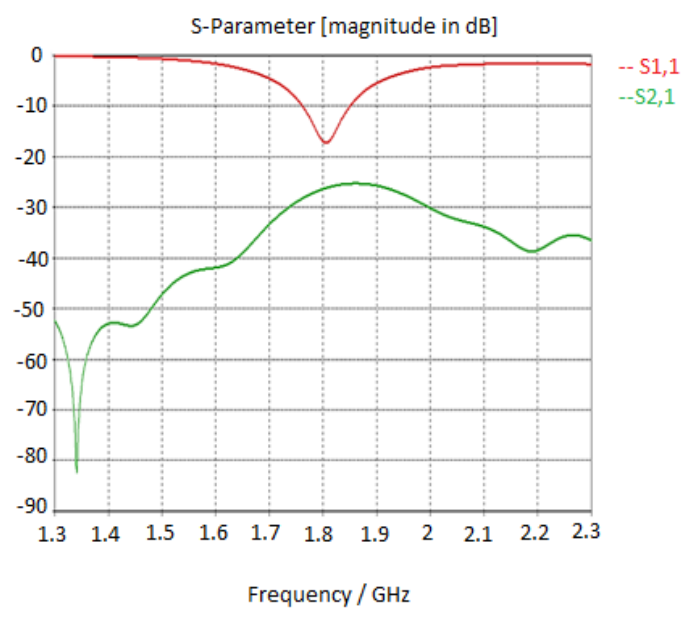

Fig. 9. S11 and S21 parameter of the paired GPR antenna.

Figure 9 shows the S11 and S21 parameter of the simulation of the paired GPR antenna. The notch of the $S 11$ parameter is still near to $1.8 \mathrm{GHz}$ while the peak of the S21 parameter can be observed at about $1.75 \mathrm{GHz}$ until 2 $\mathrm{GHz}$ at about $-25 \mathrm{~dB}$ magnitude.

\subsection{GPR PROFILE IMAGE}

The use of the GPR profile image is to show the present of any object underground. In the 
GPR system simulation, the GPR profile image constructed show several marks as shown in Figure 10 to Figure 14.

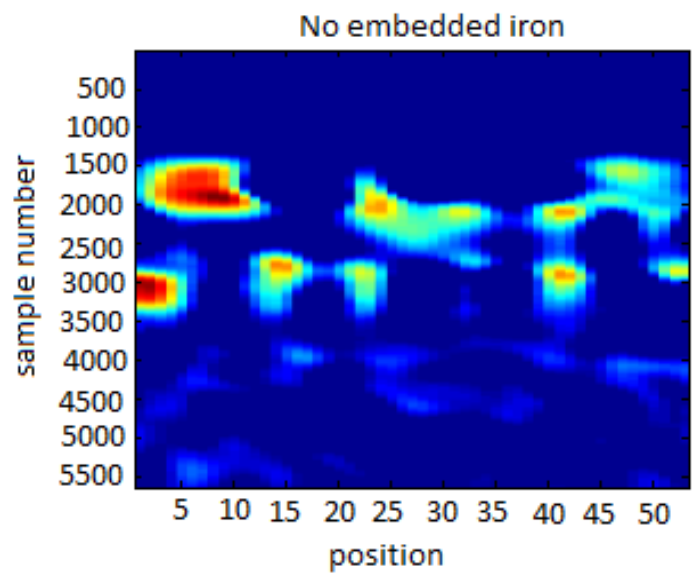

Fig. 10. GPR profile image for scanning ground with no embedded iron.

In Figure 10, the mark shown is considered a noise signal which should be ignored. Figure 11 shows a red mark at position 19 to 25 . Based on the simulation designed, this can be considered as noise.

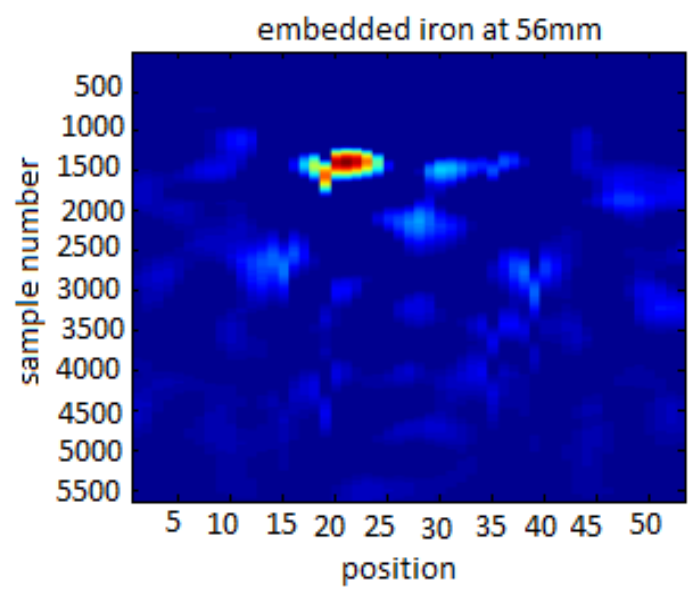

Fig. 11. GPR profile image for scanning ground with embedded iron at $56 \mathrm{~mm}$ depth.

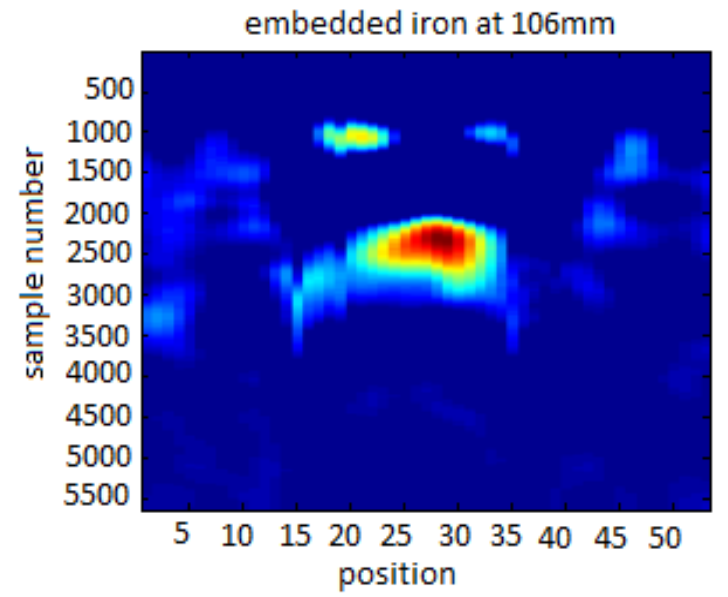

Fig. 12. GPR profile image for scanning ground with embedded iron at $106 \mathrm{~mm}$ depth.

Referring to Figure 12, red mark at position 25 to 30 can be considered as the reflection signal produced by the embedded iron. However, the sample numbers which can be translated to the depth seem to be incorrect.

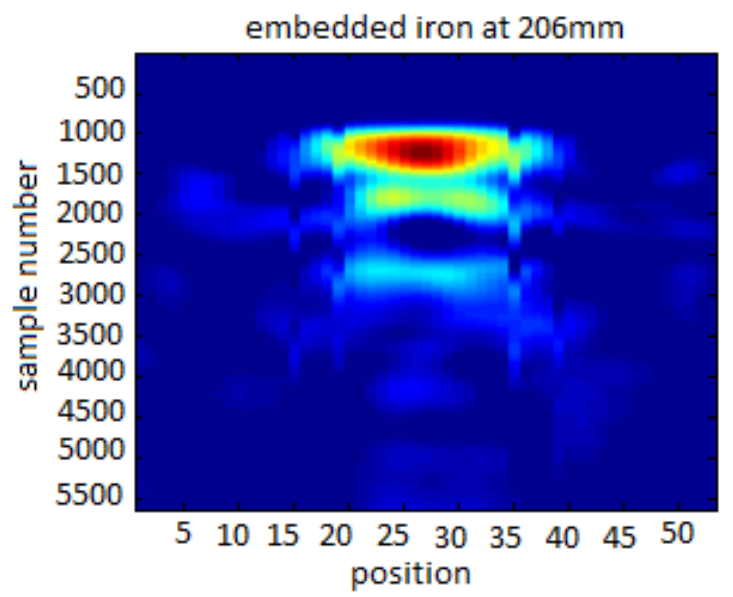

Fig. 13. GPR profile image for scanning ground with embedded iron at $206 \mathrm{~mm}$ depth.

The GPR profile of Figure 13 also shows the red marks at position 20 until 35. The reflection signal of iron buried in the middle of the ground can be estimated. The sample numbers which can be used to estimate the depth of the iron seem to be incorrect value. 


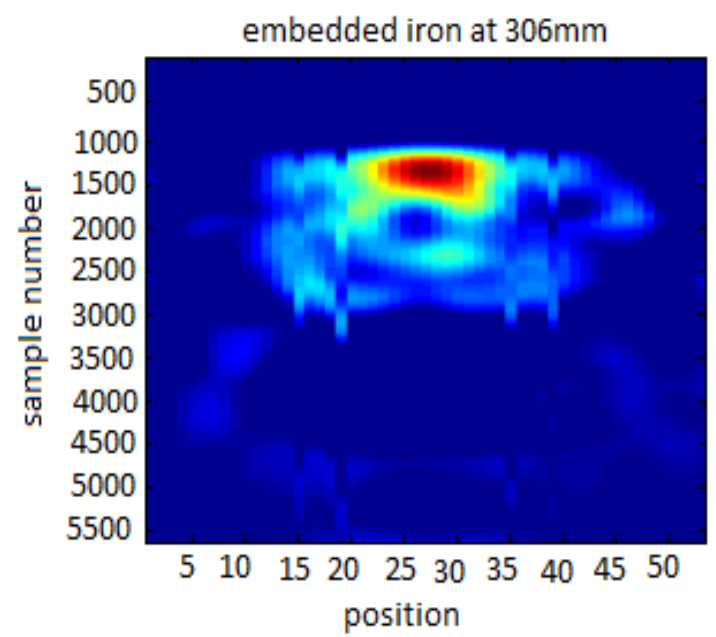

Fig. 14. GPR profile image for scanning ground with embedded iron at $306 \mathrm{~mm}$ depth.

Analyzing Figure 14, the GPR profile image seem can be used to estimate the position and depth of the iron correctly. It shows that the iron can be said to be buried at the position of 20 to 35 .

\section{CONCLUSION}

The simulation of the GPR system has been developed using CST and MATLAB software. The GPR antenna used was the rectangular microstrip patch antenna resonates at 1.8 GHz. Based on the GPR profile images of the simulation system, the estimated buried object can be done correctly if the position of iron was at depth of about $206 \mathrm{~mm}$ and $306 \mathrm{~mm}$. This was due to the parameter set to the frequency of the system which was from 1.3 $\mathrm{GHz}$ to $2.3 \mathrm{GHz}$. In the future, the orientation of the antenna will be studied in order to obtain a good GPR profile image of the simulation of GPR system.

\section{ACKNOWLEDGEMENT}

The authors would like to thank Universiti Tun Hussein Onn Malaysia for the technical support and the financial support under the Multi-Disciplinary Research Grant Scheme.

\section{REFERENCES}

[1] Liu, D. W. Deng, Y., Yang, F. and Xu, G. Y. (2005). Nondestructive testing for crack of tunnel lining using GPR. Journal of Central South University of Technology, 12(1), 120-124.

[2] He, X. Q., Zhu, Z. Q., Liu Q. Y. and Lu, G. Y. (2009). Review of GPR rebar detection. In: PIERS Proceedings, 804-813.

[3] Verma, S. K. and Bhadauria, S. and Akhtar, S. (2013). Review of nondestructive testing methods for condition monitoring of concrete structures. Journal of Construction Engineering, 1-12.

[4] Lauro, S. E., Mattei, E., Barone, P. M., Pettinelli, E., Vannaroni, G., Valerio, G., Comite, D. and Galli, A. (2013). Estimation of subsurface dielectric target depth for GPR planetary exploration: Laboratory measurements and modeling. Journal of Applied Geophysics, 93, 93100.

[5] Valerio, G., Galli, A., Barone, P. M, Lauro, S. E, Mattei, E. dan Pettinelli, E. (2012). GPR detectability of rocks in a Martian-like shallow subsoil: A numerical approach. Planetary and Space Science, 62, 31-40.

[6] Galli A., Comite D., Valerio G. and Pettinelli E. (2013). Numerical study on the critical detection of subsurface dielectric scatterers with GPR systems. In: 7th European Conference on Antennas and Propagation, 3361-3364.

[7] Desai, A. S., Wilkinson A. J. and Inggs M. R. (2001). GPR SAR simulation and image reconstruction. In: Geoscience and Remote Sensing Symposium, 5, 2076-2078.

[8] Galli, A., Comite, D., Catapano, I., Gennarelli, G., Soldovieri, F. and Pettinelli. E. (2013). 3D imaging of buried dielectric targets with a tomographic microwave approach applied to GPR synthetic data. International Journal of Antennas and Propagation, 1-10.

[9] B. Garg, B., Verma, R. D. and Samadhiya, A. (2012). Design of rectangular patch antenna incorporated with innovative metamaterial structure for dual band operation and amelioration in patch antenna parameters with negative $\mu$ and $\varepsilon$. International Journal of Engineering and Technology, 1(3), 205-216. 
[10] Soldovieri, F., I. Catapano, I., Barone, P. M., Lauro, S. E., Mattei, E., Pettinelli, E., Valerio, G., Comite, D. and Galli, A. (2013). GPR estimation of the geometrical features of buried metallic targets in testing conditions. Progress in Electromagnetics Research B. 49, 339-362.

[11] Prasad, R. K., Srivastava, D. K. and Saini, J. P. (2016). Gain and bandwidth enhancement of rectangular microstrip antenna by loading slot. 1st International Conference on Innovation and Challenges in Cyber Security (ICICCS 2016).

[12] Mishra, R. D. and Singhal, P. K. (2016). Gain enhancement of rectangular microstrip patch antenna designed for exposure system using microstrip array. International Journal of Signal Processing, Image Processing and Pattern Recognition, 9(5), 417-430.

[13] Pasternack, E. (n.d.). Microstrip patch antenna calculator. Retrieved from http://www.pasternack.com/t-calculatormicrostrip-ant.aspx.
[14] Millington, T. M., Cassidy, N. J., Crocco, L. dan Soldovieri, F. (2011). Using FDTD modelling to inform the tomographic imaging of buried utility pipes via GPR investigation. 6th International Workshop on Advanced Ground Penetrating Radar (GPR), Aachen: IEEE, 1-6.

[15] Pastemak, M. and Silko, D. (2010). Software for simulation of electromagnetic waves propagation through the soil with buried objects. 11th International Radar Symposium (IRS) 2010. Vilnius, Lithuania.: IEEE, 1-4.

[16] CST-Computer Simulation Technology. (2016). The Finite Integration Technique. Retrieved from https://www.cst.com/ products/cstmws

[17] Podebrad, O., Clemens, M., dan Weiland (2002). New Flexible Subgridding Scheme for the Finite Integration Technique. 10th Biennial IEEE Conference on Electromagnetic Field Computation (CECF 2002), Perugia, Italy: IEEE, 1-4.Bevelacqua, P. J. (n.d.) Retrieved from http://www.antenna-theory.com/antennas/ patches/antenna.php\#introduction. 
محاكاة تصميم نظم رادار الاختراق الأرضي باستخدام برمجيات الميكرويف للموجات فوق الصوتية و برنامج الماتلاب

\author{
ارفودان جوريت 1، عبداله 1، محمد سولونج 1 \\ 1 كلية الهندة الكهربية والاكترونية، جامعة تن حسين اون ماليزيا، جوبور، مايزيا
}

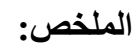

رادار الاختراق الأرضي هو نظام رادار يستخدم للكثف عن الأجسام المدفونة تحت الأرض. ويتكون هذا النظام من هو ائي يستعمل كجهاز استشعار في الكثف عن إثارات الميكروويف الصغرى التي نولدها، والتي تسىى أحادي أو ثنائي الهوائي ويستعملان كهوائي للمرسل والمستقبل، يعرف بازدواجية نظام رادار الاختراق الأرضي. ولتطوير رادار الاختراق الأرضي، لابد من محاكاة نظام رادار الاختراق الأرضي باستخدام برامج المحاكاة مثل برمجيات الموجات فوق الصوتية من أجل تقليل الأخطاء في تحديد معلمات النظام مثل أبعاد الهو ائي ونظام معالجة الإشارة. وقد بدأ تصميم نظام الدحاكاة لنظام رادار الاختراق الأرضي في هذه الدراسة بتصميم هوائي، حيث تم اختيار هو ائي التصحيح من القطاعات متناهية الصغر(ميكروستريب). ثم تحديث محاكاة تصميم الهو ائي من خلال تصميم مادة الأرضي أمام الهو ائي لإنشاء وسط الانتشار مثل التربة الرملية. ومن أجل اختبار قدرة الهوائي المصمم بوصفه نظام هوائي رادار الاختراق الأرضي وكذللك نظام معالجة الإشارات، أضيفت المادة المدفونة في الأرض. وباعتبار نظام رادار الاختراق الأرضي المقترح أنه من ضمن نظم الر ادار الاختراق الأرضي الثنائية، فإن الهو ائي يوضع بين هو ائي الإرسال والاستقبال. واستتادا إلى نظام رادار الاختراق الأرضي التجاري، فإن محاكاة نظام رادار الاختراق الأرضي سوف تفسر أيضا على أنها صورة ثنائية الأبعاد باستخدام برنامج ماتلاب. 